\section{Bed Covers Alter Temporal Distribution of Production of Sweetpotato Transplants}

\author{
Wayne C. Porter \\ Sweet Potato Research Station, Louisiana Agricultural Experiment \\ Station, Louisiana State University Agricultural Center, Chase, LA 71324
}

Additional index words. Ipomoea batatas, black polyethylene, perforated clear polyethylene, double-slitted clear polyethylene, spunbonded polyester

\begin{abstract}
Four bed covers (black polyethylene, perforated clear polyethylene, doubleslitted clear polyethylene, and spunbonded polyester) and a bare soil control were evaluated for their effect on the number, size, and harvest time of sweetpotato [Ipomoea batatas (L.) Lam. Cv. Travis] transplants. The perforated and double-slitted bed covers increased the weight and number of sweetpotato transplants compared with the control or with black polyethylene at the first harvests in 1986 and 1987. Seed roots covered with the spunbonded polyester bed cover produced more plants of greater weight than seed roots covered with bare soil at the first harvest in 1986 only. Black polyethylene treatments produced the greatest weight and number of transplants at the second harvest ( 8 to 12 days later) in both years. There were no significant differences in total weight and numbers of transplants among black polyethylene, or perforated or doubleslitted clear polyethylene treatments in 1986. Total transplant count and weights from plots covered with spunbonded polyester were lower than those from plots with any other bed covers.
\end{abstract}

The production of transplants is the largest single cost of producing a crop of sweetpotatoes (Hernandez, 1970). The quantity of "seed" potatoes required to produce the number of transplants needed to plant a hectare varies from 1120 to $1680 \mathrm{~kg}$. Factors that affect this number are: 1) size of the "seed" roots; 2) number of pullings or cuttings 3) bed management; 4) whether "seed" roots were presprouted; and 5) cultivar (Drinkwater, 1966; Montelaro and Martin, 1977; Steinbauer and Kushman, 1971; Wilson et al., 1980). A grower must take all these factors into consideration in planning a sweetpotato transplant production program.

Early field setting of transplants usually produces higher yields and better grades of roots than late plantings. Each 2 -week delay in planting reduces the yield of No. 1 grade roots $\approx 680 \mathrm{~kg} \cdot \mathrm{ha}^{-1}$ (Drinkwater, 1966; Hernandez, 1970). Additionally, the crop produced earlier in the season usually sells

Received for publication 4 Apr. 1990. The cost of publishing this paper was defrayed in part by the payment of page charges. Under postal regulations, this paper therefore must be hereby marked advertisement solely to indicate this fact.

${ }^{1}$ Present address: Hammond Res. Sta., 5925 Old

Covington Hwy., Hammond, LA 70403. for a higher price. To obtain transplants for earlier planting, most growers cover their field-bedded "seed" roots with black or clear polyethylene mulch (Montelaro and Martin, 1977; Wilson et al., 1980). The mulch is left on the bed until the sprouts emerge and then it is removed. If the mulch is removed too late, terminals of the emerging plants may be killed.

Many sweetpotato growers prefer 'Travis' because it reaches harvestable size $\approx 90$ days from transplanting and is resistant to soil rot [Streptomyces ipomoea (Person \& W.J. Martin) Waks. \& Henrici] (Hernandez et al., 1981), an important disease in most sweetpotato growing areas (Montelaro and Martin, 1977; Steinbauer and Kushman, 1971; Wilson et al., 1980). This cultivar has a history of poor plant production. Walker and Randle (1986) used various row covers and a black polyethylene mulch to increase the number of large transplants that were produced by 'Travis' roots bedded early in the spring. The total number of transplants was not necessarily increased. Walker and Randle (1986) did not determine the temporal distribution of transplant production in their row cover studies. Sweetpotato growers harvest plants from the transplant production beds several times during the season. Therefore, this study was designed to investigate the effect of var- ious bed covers on the distribution of 'Travis' transplant harvest time and specifically to determine whether other types of bed covers would increase early plant production compared with black polyethylene or bare soil.

The study was conducted in 1986 and 1987 at the Sweet Potato Research Station, Chase, La., on a Gilbert silt loam (fine silty, mixed, thermic Typic Glossaqualfs) with $\mathrm{pH} 5.1$ and $<1 \%$ organic matter.

Each plot was $4.6 \mathrm{~m}$ long and $0.3 \mathrm{~m}$ wide on raised beds that were $1.2 \mathrm{~m}$ wide. Fertilizer $\left(40 \mathrm{~N}-219 \mathrm{P}-208 \mathrm{~K}, \mathrm{~kg} \cdot \mathrm{ha}^{-1}\right)$ was incorporated before planting. These studies were initiated 27 Mar. 1986 and 23 Mar. 1987. About 75 'Travis' sweetpotato roots (11.5 $\mathrm{kg}$ ) of uniform size were placed in each plot. Before bedding, the roots were dipped in a suspension of 2,6-dichloro-4-nitroaniline (Botran 75W, $16 \mathrm{~g} \cdot$ liter $^{-1}$ ) and 2-(4-thiazolyl) benzimidazole (Mertect 340,8 $\mathrm{ml} \cdot$ liter $^{-1}$ ). After the roots were covered with soil, an experimental herbicide, alachlor [(2-chloro$\mathrm{N}$-(2,6-diethylphenyl)- $N$-(methoxymethyl)acetamide), $2.2 \mathrm{~kg} \cdot \mathrm{ha}^{-1}$ ], was applied for weed control. Supplemental irrigation was supplied as needed during the growing period.

Since all the materials used to cover the beds were laid directly on the soil, all the treatments are referred to as bed covers. The treatments evaluated in this study were: 1) black polyethylene $(38 \mu \mathrm{m}$ thick, $120 \mathrm{~cm}$ wide; local source); 2) perforated clear polyethylene $(25 \mu \mathrm{m}$ thick, $150 \mathrm{~cm}$ wide, twelve $1.2-\mathrm{cm}$ holes per $100 \mathrm{~cm}^{2}$, Agplast, Ont., Canada); 3) double-slitted clear polyethylene (28 $\mu \mathrm{m}$ thick, $150 \mathrm{~cm}$ wide, with slits 12 $\mathrm{cm}$ long every $3 \mathrm{~cm}$ in rows $36 \mathrm{~cm}$ apart); 4) spunbonded polyester $(25 \mu \mathrm{m}$ thick, 170 $\mathrm{cm}$ wide); and 5) a bare soil control (covers 3 and 4, Ken-Bar, Reading, Mass.). 'fire black polyethylene was applied tightly to the soil. The other bed covers were applied loosely to the row without support. The black polyethylene was removed when the sweetpotato sprouts were $\approx 3 \mathrm{~cm}$ tall, which is the normal practice. The remaining bed covers were not removed until the first transplants were ready to be harvested. The treatments were laid out in a randomized complete-block design with four replications. All treatments were harvested when' the first transplants for any treatment were $20 \mathrm{~cm}$ tall (minimum transplant size). Transplants were harvested four times, beginning on 22 May 1986 and 21 May 1987 with subsequent harvests at 8- to 12-day intervals.

Data were evaluated with an analysis of variance. Means were separated using the least significant difference at $P=0.05$.

Perforated, double-slitted, and spunbonded 
Table 1. Effects of row covers on weight and number of 'Travis' sweetpotato transplants per square meter during several harvests, 1986 and 1987.

\begin{tabular}{|c|c|c|c|c|c|c|c|c|c|c|c|}
\hline \multirow[b]{3}{*}{ Cover } & \multicolumn{8}{|c|}{ Harvest date } & & & \multirow{3}{*}{$\begin{array}{l}\text { Avg wt } \\
\text { (g/plant) }\end{array}$} \\
\hline & \multicolumn{2}{|c|}{22 May } & \multicolumn{2}{|c|}{3 June } & \multicolumn{2}{|c|}{13 June } & \multicolumn{2}{|c|}{23 June } & \multicolumn{2}{|c|}{ Total } & \\
\hline & $\mathrm{kg}$ & no. & $\mathrm{kg}$ & no. & $\mathrm{kg}$ & no. & $\mathrm{kg}$ & no. & $\mathrm{kg}$ & no. & \\
\hline \multicolumn{12}{|c|}{1986} \\
\hline None (bare soil) & 0.00 & 0 & 2.25 & 70 & 1.11 & 52 & 0.41 & 31 & $3.77^{\prime}$ & 153 & 24.9 \\
\hline Black polyethylene & 0.02 & 2 & 3.19 & 159 & 0.89 & 45 & 0.62 & 28 & 4.73 & 234 & 20.2 \\
\hline Perforated polyethylene & 1.68 & 112 & 1.32 & 56 & 0.98 & 50 & 0.35 & 25 & 4.32 & 243 & 17.8 \\
\hline Double-slitted polyethylene & 1.18 & 72 & 1.65 & 61 & 1.07 & 57 & 0.31 & 20 & 4.21 & 210 & 20.4 \\
\hline Spunbonded polyester & 1.08 & 57 & 1.08 & 50 & 0.50 & 28 & 0.20 & 17 & 2.48 & 152 & 19.1 \\
\hline LSD $(0.05)$ & 0.35 & 32 & 0.83 & 34 & 0.35 & NS & 0.24 & NS & 0.98 & 50 & 4.4 \\
\hline \multicolumn{12}{|c|}{1987} \\
\hline & \multicolumn{2}{|c|}{21 May } & \multicolumn{2}{|c|}{29 May } & \multicolumn{2}{|c|}{9 June } & \multicolumn{2}{|c|}{18 June } & & & \\
\hline None (bare soil) & 0.00 & 0 & 0.35 & 27 & 0.95 & 51 & 0.37 & 36 & 1.67 & 113 & 14.9 \\
\hline Black polyethylene & 0.06 & 6 & 1.46 & 136 & 1.00 & 95 & 0.48 & 57 & 3.00 & 294 & 10.1 \\
\hline Perforated polyethylene & 0.65 & 57 & 0.39 & 34 & 0.67 & 46 & 0.39 & 37 & 2,08 & 174 & 12.0 \\
\hline Double-slitted polyethylene & 0.74 & 66 & 0.29 & 25 & 1.09 & 85 & 0.55 & 65 & 2.67 & 241 & 11.2 \\
\hline Spunbonded polyester & 0.16 & 10 & 0.26 & 16 & 0.59 & 35 & 0.28 & 28 & 1.28 & 89 & 14.9 \\
\hline LSD $(0.05)$ & 0.32 & 24 & 0.42 & 32 & NS & 29 & NS & 1 & 0.65 & 57 & 2.9 \\
\hline
\end{tabular}

polyester bed covers increased the number and weight of sweetpotato transplants at the first harvest in 1986 compared with the bare soil or black polyethylene (Table 1). The perforated bed cover resulted in a greater number and weight of transplants than all other treatments at the first harvest. At the second harvest, 12 days later, the number and weight of transplants produced under the black polyethylene were significantly greater than in any other treatment. The weight of transplants from the plots covered with the spunbonded polyester was lower than the weight from all other treatments at the third harvest, but was only lower than the weight from plots covered with black polyethylene at the last harvest. There was no difference among treatments in the number of transplants at the last two harvests. The total number and weight of transplants from spunbonded polyester plots were less than from black polyethylene plots. There were no differences in total plant weigh or number of plants among the black polyethylene mulch, perforated, or double-slitted, clear polyethylene treatments. The average weight of plants from the bare soil plots was higher than that from any other treatment.

Roots jn beds covered with perforated or double-slitted polyethylene produced the greatest number and weight of transplants at the first harvest in 1987 (Table 1). As in 1986, the weight and number of transplants from beds covered with black polyethylene were higher than from any other treatment at the second harvest. At the third and fourth plant harvests, there were no differences in the weight of transplants. Black polyethylene and the double-slitted covered plots usually produced the most transplants at these harvests. Yield of plants from plots covered with black polyethylene did not differ from those covered with perforated polyethylene at the fourth harvest. Black polyethylene and the double-slitted covered plots produced the greatest total number of transplants. There were no significant differences among the black polyethylene, perforated, or doubleslitted covers in total number or weight of transplants produced. Average plant weight was greatest from roots in the bare soil and spunbonded polyester treatments.

When the black polyethylene mulch was removed, all potential soil-warming properties were lost. The other bed covers presumably continued to provide a warm environment in which the emerging plants could grow. The perforated and double-slitted row covers probably warmed the soil and air better than the spunbonded polyester (Motsenbocker and Bonanno, 1989; Walker and Randle, 1986). When heavy rainfall pounded the spunbonded polyester, it adhered to the soil, and the first plants to emerge were bent and twisted. Use of either the perforated or double-slitted covers as opposed to the black plastic mulch increased early transplant production of sweetpotatoes by 8 to 12 days and time of removal was not as critical. Early transplant production with these bed covers could provide the economic advantages described by Drinkwater (1966) and Hernandez
(1970). Also, openings in these covers should allow $\mathrm{CO}_{2}$ to escape and $\mathrm{O}_{2}$ to enter, thereby minimizing decay and overheating (Wilson et al., 1980). These advantages could be beneficial to farmers who grow their own transplants and who are trying to produce sweetpotatoes for the early market.

\section{Literature Cited}

Drinkwater, W.O. 1966. Sweetpotato plant production by removal of proximal dominance in roots. N.J. Agr. Expt. Sta. Veg. Mimeo Ser. 14.

Hernandez, T.P. (cd.). 1970. Thirty years of cooperative sweet potato research 1939-1969. Southern Coop. Ser. Bul. 159.

Hernandez, T. P., R.J. Constantin, H.L. Hammett, W.J. Martin, and L. Rolston. 1981 'Travis' sweet potato. HortScience 16:574.

Montelaro, J. and W.J. Martin. 1977. Sweetpotatoes in Louisiana. La. Coop. Ext. Serv. Publ. 1450.

Motsenbocker. C.E. and A.R. Bonanno. 1989 Row cover effects on air and soil temperatures and yield of muskmelon. HortScience 24:601603

Steinbauer, C.E. and L.J. Kushman. 1971. Sweetpotato culture and diseases. U.S. Dept. Agr.-Agr. Res. Serv. Hdbk. no. 388.

Walker, D.W. and W.M. Randle. 1986. Influence of row covers, mulch, and bedding dates on early production of sweet potato transplants. HortScience 21:1354-1356.

Wilson, L. G., C.W. Averre, J.V. Baird, E.A. Estes, K.A. Sorenson, E.O. Beasley, and W.A. Skroch. 1980. Growing and marketing quality sweet potatoes. N.C. Coop. Ext. Serv. Bul. AG09. 